\title{
PRAKTIK AKAD WAKALAH PADA BMT AMANAH BERSAMA BOJONEGORO PERSPEKTF HUKUM ISLAM
}

\author{
Nabillah Febri Annisa \\ UIN Sunan Ampel, Surabaya \\ nadyafat0307@gmail.com
}

Nabrina Nur Zeninda

UIN Sunan Ampel, Surabaya

nina.zeninda@gmail.com

Nadya Fatma Kholili

UIN Sunan Ampel, Surabaya

nadyafat0307@gmail.com

Rosa Novitasari Aisyah

UIN Sunan Ampel, Surabaya

rosanovita577@gmail.com

\author{
Ulil Ala'i \\ UIN Sunan Ampel, Surabaya \\ ulilalai99@gmail.com
}

\begin{abstract}
This article discusses the practice of wakalah contracts at BMT Amanah with Bojonegoro. This research is field research. Data collection was carried out through interviews, observation, and documentation. The collected data were analyzed deductively. Baitul Mal wat Tamwil (BMT) is a micro institution that is operated on the principle of profit-sharing, growing, and developing micro-business to elevate the degree and dignity and defend the interests of the poor. In the BMT Amanah Bersama, the most frequently used financing is the murabahah contract but still does not rule out other contracts such as the wakalah contract. The wakalah contract at BMT Amanah Bersama does not stand alone, but from the wakalah contract, the BMT can receive income earned through ujrah (fees) which is used as a reciprocal between the BMT institution and the customer so that both are mutually beneficial. Based on this practice, the wakalah contract carried out at BMT Amanah Bersama is by the principles of Islamic law.
\end{abstract}

Keywords: Wakalah, BMT, Amanah Bersama, Islamic Law.

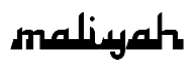

Jurnal Hukum Bisnis Islam

Volume 9, Nomor 01, Juni 2019

p-ISSN: 2088-4869/ e-ISSN: 2597-4351 
Nabillah Febri Annisa, Nabrina Nur Zeninda, Nadya Fatma Kholili, Rosa Novitasari Aisyah, Ulil Ala'i

Abstrak: Artikel ini membahas tentang praktik akad wakalah di BMT Amanah Bersama Bojonegoro. Penelitian ini adalah penelitian lapangan. Pengumpulan data dilakukan melalui wawancara, observasi dan dokumentasi. Data yang terkumpul dianalisis secara deduktif. Baitul Mal wat Tamwil (BMT) merupakan lembaga mikro yang dioperasikan dengan prinsip bagi hasil, menumbuh kembangkan bisnis usaha mikro dalam rangka mengangkat derajat dan martabat serta membela kepentingan kaum fakir miskin. Dalam BMT Amanah Bersama pembiayaan yang paling sering digunakan adalah akad murabahah akan tetapi tetap tidak mengesampingkan akad-akad lain seperti akad wakalah. Akad wakalah di BMT Amanah Bersama tidak berdiri sendiri akan tetapi dari akad wakalah pihak BMT dapat menerima pendapatan yang diperoleh melalui ujrah (fee) yang mana ini digunakan sebagai timbal balik antara lembaga BMT tersebut dengan nasabah agar kedua-keduanya saling menguntungkan. Berdasarkan praktik tersebut, akad wakalah yang dilakukan di BMT Amanah Bersama telah sesuai dengan prinsip hukum Islam.

Kata Kunci: Wakalah, BMT, Amanah Bersama, Hukum Islam.

\section{Pendahuluan}

Dalam kehidupan saat ini perlu kiranya kita mengetahui dan memahami akad-akad dalam bermuamalah. Akad wakalah (perwakilan) merupakan salah satu akad yang diajarkan di dalam hukum Islam dengan bersumber pada al-Qur'an dan Hadis, maupun kitab-kitab klasik yang telah dibuat oleh para ulama terdahulu, yang menjelaskan tentang bagaimana seharusnya wakalah diaplikasikan dalam kehidupan seharihari.

Wakalah sangat berperan penting dalam kehidupan sehari-hari, karena wakalah dapat membantu seseorang dalam melakukan pekerjaan yang tidak dapat dilakukan oleh orang tersebut tetapi pekerjaan tersebut masih dapat dilakukan oleh orang lain seperti selayaknya yang telah direncanakan. Hukum wakalah adalah diperbolehkan, karena dianggap sebagai sikap tolong-menolong antar sesama, selama wakalah tersebut bertujuan kepada kebaikan.

Lahirnya lembaga Baitul Mal Wat Tamwil (BMT) memberi titik terang bagi usaha menengah dan mikro. Kehadiran BMT di tengah-tengah koperasi konvensional telah menawarkan sistem perbankan alternatif bagi umat Islam 
yang membutuhkan atau ingin memperoleh layanan maupun jasa perbankan tanpa melanggar larangan riba. ${ }^{1}$ Baitul Mal Wat Tamwil (BMT) mulai populer diperbincangkan oleh insan perekonomian terutama dalam perekonomian Islam. Baitul Mal wat Tamwil (BMT) merupakan lembaga mikro yang dioperasikan dengan prinsip bagi hasil, ${ }^{2}$ menumbuh kembangkan bisnis usaha mikro dalam rangka mengangkat derajat dan martabat serta membela kepentingan kaum fakir miskin. Ciri khas dari BMT adalah memadukan antara layanan sosial dengan layanan komersial serta menerapkan sistem bagi hasil yang sangat sesuai dengan kebutuhan para pelaku usaha mikro kecil.

Diantara beberapa produk yang dikeluarkan oleh BMT paling banyak digunakan adalah produk yang menggunakan akad Murabahah. Terutama pada pembiayaan karena dinilai prosesnya tidak serumit di perbankaan syari'ah. Akad Murabahah tidak terlepas dari akad wakalah dimana akad wakalah merupakan akad yang digunakan untuk pelimpahan kekuasaan oleh seseorang sebagai pihak pertama kepada orang lain sebagai pihak kedua dalam hal-hal yang diwakilkan (dalam hal ini pihak kedua) hanya melaksanakan sesuatu sebatas kuasa atau wewenang yang diberikan oleh pihak pertama, namun apabila kuasa itu telah dilaksanakan sesuai yang disyaratkan, maka semua resiko dan tanggung jawab atas dilaksanakan perintah tersebut sepenuhnya menjadi pihak pertama atau pemberi kuasa.

Akad wakalah merupakan akad tambahan sebagai pelengkap yaitu akad pemberian kuasa dari pihak bank kepada calon nasabah untuk membeli barang sesuai dengan kesepakatan didalam pejanjian pembiayaan. Dalam akad murabahah, BMT menggunakan akad wakalah agar nasabah

${ }^{1}$ Novita Dewi Masyithoh, “Analisis Normatif Undang-Undang No. 1 Tahun 2013 Tentang Lembaga Keuangan Mikro (Lkm) Atas Status Badan Hukum Dan Pengawasan Baitul Maal Wat Tamwil (Bmt)," Economica: Jurnal Ekonomi Islam 5, no. 2 (2014): 17-36, https://doi.org/10.21580/economica.2014.5.2.768.

2 Muljadi, "Prospek Baitul Maal Wat Tamwil (BMT) Dalam Memajukan Pengusaha Mikro," Dynamic Management Journal 1, no. 2 (2017), 2. 
dapat membeli barang sebagai mewakili bank untuk membeli barang secara tunai. Akad wakalah dapat dijadikan sarana untuk mewakilkan secara syari'ah.

Di Bojonegoro terdapat BMT Amanah Bersama, yang memiliki produk-produk jasa keuangan yang dilandaskan pada syariat Islam. Berdasarkan hal di atas, artikel ini membahas tentang praktik akad wakalah pada BMT Amanah Bersama Bojonegoro.

Artikel ini adalah hasil penelitian lapangan yang bersifat kualitatif, dengan pengumpulan data melalui observasi dengan mengunjungi BMT Amanah bersama, wawancara dengan pihak pengelola BMT dan melalui dokumentasi dengan mempelajari berkas-berkas dokumen yang berkaitan dengan BMT Amanah bersama. Data yang terkumpul dianalisis dengan hukum Islam secara deduktif untuk mengambil kesimpulan yang khusus.

\section{Pengertian Wakalah}

Al-Wakalah atau al-wikalah bermakna al-tafwidh yang berarti penyerahan, pendelegasian atau pemberian mandat. ${ }^{3}$ Yang dimaksud wakalah dalam hal ini adalah pelimpahan kekuasaan oleh seseorang sebagai pihak pertama kepada orang lain sebagai pihak kedua dalam hal-hal yang diwakilkan. Dalam hal ini, pihak kedua hanya melaksanakan sesuatu sebatas kuasa atau wewenang yang diberikan oleh pihak pertama, namun apabila kuasa tersebut telah dilaksanakan sesuai yang diisyaratkan, maka semua resiko dan tanggung jawab atas dilaksanakannya perintah tersebut sepenuhnya menjadi tanggungjawab pihak pertama atau pemberi kuasa. ${ }^{4}$

Dalam praktik perbankan, wakalah lazim diaplikasikan untuk produk transfer uang. Dalam hal ini, nasabah bertindak sebagai muwakkil, yakni pihak yang mewakilkan pekerjaan

\footnotetext{
${ }^{3}$ Aunur Rohim Faqih, Bank Syariah, Kontrak Bisnis Syariah, \& Penyelesaian Sengketa Di Pengadilan (Yogyakarta: FH UII Press, 2017), 65.

${ }^{4}$ Fatmah, Kontrak Bisnis Syariah (Surabaya: UIN Sunan Ampel Press, 2014), 210.
} 
transfer uang kepada pihak yang dituju, sedangkan pihak bank bertindak sebagai wakil dari nasabah, dan taukilnya berupa transfer uang. Untuk transaksi transfer uang tersebut, biasanya nasabah akan membayarkan sejumlah uang sebagai fee..$^{5}$

Wakalah mempunyai beberapa makna yang berbeda menurut beberapa ulama, berikut ini adalah masing-masing pandangan dari para ulama:

1. Menurut Hasby Ash shiddieqy, wakalah adalah akad penyerahan kekuasaan yang pada akad itu seseorang menunjuk orang lain sebagai penggantinya dalam bertindak. 6

2. Menurut Ulama Malikiyah, wakalah adalah tindakan seseorang mewakilkan dirinya kepada orang lain untuk melakukan tindakan-tindakan yang merupakan haknya yang tindakan itu tidak dikaitkan dengan pemberian kuasa setelah mati, sebab jika dikaitkan dengan tindakan setelah mati berarti sudah berbentuk wasiat.

3. Menurut ulama Syafi'iyah wakalah adalah salah suatu ungkapan yang mengandung suatu pendelegasian sesuatu oleh seseorang kepada orang lain supaya orang lain itu melaksanakan apa yang boleh dikuasakan atas nama pemberi kuasa.

\section{Dasar Hukum}

Salah satu dasar dibolehkannya al-wakalah adalah firman Allah SWT berkenaan dengan kisah Ash-habul Kahfi;

"Dan demikianlah Kami bangkitkan mereka agar saling bertanya di antara mereka sendiri. Berkata salah seorang di antara mereka, 'Sudah berapa lamakah kamu berada disini?' mereka menjawab, 'Kita sudah berada (disini) satu atau setengah hari.' Berkata (yang lain lagi), 'Tuhan kamu lebih mengetahui berapa lama kamu

\footnotetext{
${ }^{5}$ Ibid, hlm 66

6 Teungku Muhammad Hasby Ash Shiddieqi, Hukum-Hukum Fiqh Islam (Semarang: PT Pustaka Rizki Putra, 2001), 391.
} 
berada (disini). Maka, suruhlah salah seorang diantara kamu pergi ke kota dengan membawa uang perakmu ini dan hendaklah ia lihat manakah makanan yang lebih baik dan hendaklah ia membawa makanan itu untukmu, dan hendaklah ia berlaku lemah lembut, dan janganlah sekali-kali menceritakan halmu kepada seseorang pun." (al- Kahfi:19)

Ayat ini melukiskan perginya salah seorang ashhabul kahfi yang bertindak untuk dan atas nama rekan-rekannya sebagai wakil mereka dalam memilih dan membeli makanan.

Ayat lain yang menjadi rujukan al-wakalah adalah kisah tentang nabi Yusuf a.s. saat ia berkata kepada raja;

"Jadikanlah aku bendaharawan negara (Mesir); sesungguhnya aku adalah orang yang pandai menjaga, lagi berpengetahuan“. (QS. Yusuf: 55).

Dalam konteks ayat ini, nabi Yusuf siap untuk menjadi wakil dan pengemban amanah menjaga "Federal Reserve" negeri Mesir.

Terdapat hadis yang dapat dijadikan landasan keabsahan wakalah, diantaranya:

"Bahwasanya Rasulullah SAW mewakilkan kepada Abu

Rafi'i dan seorang Anshar untuk mewakili mengawini Maimunah binti al- Harits." (HR. Malik no.678 kitab alMuwaththa', Bab Haji).

Dalam kehidupan sehari-hari, Rasulullah SAW telah mewakilkan kepada orang lain untuk berbagai urusan. Di antaranya adalah membayar hutang, mewakilkan penetapan had dan membayarnya, mewakilkan pengurusan unta, membagi kandang hewan dan lain-lainnya.

Para ulama bersepakat dengan ijma' atas dibolehkannya wakalah. Mereka bahkan ada yang cenderung mensunnahkannya dengan alasan bahwa hal tersebut termasuk jenis ta'awun atau tolong-menolong atas dasar kebaikan dan takwa. Tolong menolong diserukan oleh AlQur'an dan disunnahkan oleh Rasulullah SAW.

Allah berfirman; 
“...Dan, tolong-menolonglah kamu dalam (mengerjakan) kebajikan dan takwa, dan janganlah kamu tolongmenolong dalam (mengerjakan) dosa dan permusuhan..." (Al-Maidah: 2)

Rasulullah saw. Bersabda;

"dan, Allah menolong hamba selama hamba menolong saudaranya." (HR. Muslim no 4867, kitab az-Zikr)

Dalam perkembangan hukum Islam, terjadi perbedaan pendapat mengenai status wakalah:

1. Pendapat pertama menyatakan bahwa niyabah atau mewakili. Menurut pendapat ini si wakil tidak dapat menggantikan seluruh fungsi muwakil.

2. Pendapat kedua menyatakan bahwa wakalah adalah wilayah, karena khilafah (menggantikan) di bolehkan untuk yang menyerahkan kepada yang lebih baik. Sebagaimana dalam jual beli, melakukan pembayaran secara tunai lebih baik walaupun diperkenankan secara kredit. ${ }^{7}$

\section{Rukun dan Syarat}

Rukun dari akad wakalah yang harus dipenuhi dalam transaksi ada beberapa hal, yaitu:

1. Muwakil atau pelaku kad (pemberi kuasa) adalah pihak yang memberikan kuasa kepada pihak lain.

2. Wakil (penerima kuasa)

3. Taukil, yaitu objek akad atau objek yang dikuasakan

4. Sighat yaitu ijab dan qabul. ${ }^{8}$

Adapun syarat-syarat akad wakalah, yaitu:

1. Muwakil (Pemberi kuasa)

Seorang yang menerima kuasa harus sehat akal dan pikiran serta harus cakap perbuatan hukum.

2. Wakil (Penerima kuasa)

Seorang wakil disyaratkan harus cakap melakukan perbuatan hukum dan berakal sehat.

\footnotetext{
${ }^{7}$ Muhammad Syafii Antonio, Bank Syariah: Dari Teori Ke Praktik (Jakarta: Gemma Insani, 2001), 120-123.

${ }^{8}$ Ascarya, Akad Dan Produk Bank Syariah (Jakarta: Rajawali Press, 2013), 104.
} 
Nabillah Febri Annisa, Nabrina Nur Zeninda, Nadya Fatma Kholili, Rosa Novitasari Aisyah, Ulil Ala'i

3. Taukil (Objek yang dikuasakan)

Taukil atau objek yang dikuasakan harus jelas dan serta tidak bertentangan dengan syariat Islam.

4. Sighat (Ijab dan qabul)

Pernyataan ijab dan qabul harus dinyatakan oleh para pihak untuk menunjukkan kehendak mereka dalam mengadakan kontrak (akad).

\section{Fatwa DSN MUI tentang Akad Wakalah}

Melalui fatwa DSN Nomor 10/DSN-MUI/IV/2000 tentang wakalah menetapkan hukum wakalah bahwa akad wakalah sah adanya dan tidak bertentangan dengan syariah. Selain itu dari konsiderans seimbang dapat diketahui pula pertimbangan Dewan Syariah Nasional dalam menetapkan fatwa mengenai kegiatan wakalah, adalah sebagai berikut:

1. Bahwa dalam rangka mencapai suatu tujuan, sering diperlukan pihak lain untuk mewakilinya melalui akad wakalah, yaitu pelimpahan wewenang oleh satu pihak kepada pihak lain dalam hal-hal yang boleh diwakilkan.

2. Bahwa praktik wakalah dalam Lembaga Keuangan Syariah dilakukan sebagai salah satu bentuk pelayanan jasa perbankan kepada nasabah.

3. Bahwa praktik wakalah tersebut sesuai dengan ajaran Islam, DSN memandang perlu menetapkan fatwa tentang wakalah untuk dijadikan pedoman Lembaga Keuangan Syariah.

Dalam fatwa DSN MUI Nomor 10/DSN-MUI/IV/2000 ditetapkan ketentuan tentang wakalah sebagai berikut:

1. Pernyataan ijab dan qabul harus dinyatakan oleh para pihak untuk menunjukkan kehendak mereka dalam mengadakan kontrak (akad).

2. Wakalah dengan imbalan bersifat mengikat dan tidak boleh dibatalkan secara sepihak. ${ }^{9}$

\footnotetext{
${ }^{9}$ Dewan Syariah Nasional Majelis Ulama Indonesia, "Fatwa DSN MUI Nomor 10/DSN-MUI/IV/2000 Tentang Wakalah" (Jakarta, 2000).
} 


\section{Ketentuan Wakalah}

Terdapat beberapa ketentuan dalam wakalah berkaitan dengan ketentuan pemberi kuasa, berakhirnya kuasa dan ketentuan teknik dalam perbankan yang dijelaskan sebagai berikut:

1. Ketentuan Pemberi Kuasa

Kuasa pada pasal 1792 KUHPerdata adalah suatu perjanjian, dimana seseorang memberi kekuasaan atau wewenang kepada orang lain yang menerimanya untuk dan atas namanya menyelenggarakan suatu urusan. ${ }^{10}$

Penerima kuasa melaksanakan kewajibannya sesuai dengan kuasa yang diberikan oleh si pemberi kuasa, semua tanggung jawab dipikul pemberi kuasa, karena si penerima kuasa melakukan perbuatan hukum atas nama pemberi kuasa atau atas tanggungan si pemberi kuasa.

Secara umum perjanjian pemberian kuasa dapat dibedakan menjadi dua macam, yakni:

a. Kuasa Umum

Kuasa Umum dalam hali ini berarti pemberian kuasa kepada orang lain yang dirumuskan dengan kata-kata umum, meliputi segala kepentingan. Isi dari kuasa umum hanya meliputi perbuatan-perbuatan pengurusan (beheer), sehingga tidak terdapat hal-hal yang sifatnya mengalihkan atau membebani hak (beschikking).

b. Kuasa Khusus

Kuasa khusus akan diberikan untuk hal-hal yang sifatnya khusus sehingga dalam surat kuasa itu harus dicantumkan kata-kata "kuasa khusus". Adapun perbuatan yang harus didasarkan pada surat kuasa khusus antara lain adalah: mengajukan perkara ke pengadilan, serta pemindah tanganan barang (menjual, menghibahkan, mewakafkan). ${ }^{11}$

Kedua macam bentuk pemberian kuasa ini, dalam Islam juga dapat dialihkan kepada pihak lain atau dilakukan kuasa

\footnotetext{
${ }^{10}$ Pasal 1792 KUHPerdata.

${ }^{11}$ Fatmah, Kontrak Bisnis Syariah, 214.
} 
substitusi. Hal ini diperbolehkan sepanjang dalam pemberian kuasa yang pertama dijelaskan secara tegas bahwa penerima kuasa mempunyai hak untuk memberikan kuasa kepada pihak lain. Apabila kuasa substitusi dilakukan tanpa didasarkan pada kebolehan sebagaimana yang tercantum di dalam surat kuasa semula, berarti bahwa penerima kuasa telah melakukan urusan di luar kewenangannya. Dalam hal terjadi yang demikian, maka konsekuensi yuridisnya adalah berupa tanggung jawab mengganti kerugian apabila yang dilakukan kuasa substitusi menimbulkan kerugian, bahkan perbuatan yang dilakukan oleh penerima kuasa semula adalah tidak sah. ${ }^{12}$

2. Berakhirnya Kuasa

Mengenai berakhirnya kuasa yang diatur dalam pasal 1813 KUHPerdata, yaitu karena pemberi kuasa menarik kembali kuasanya, pemberitaan penghentian kuasa, dan meninggalnya/pengampunnya/pailitnya si pemberi kuasa. ${ }^{13}$

Pada surat kuasa pada umumnya selalu ditentukan limit waktu atau term-term yang menjadi sebab berakhirnya sebuah perjanjian pemberian kuasa. Dengan demikian pemberian kuasa akan berakhir apabila terjadi kejadian atau kondisi sebagai berikut: ${ }^{14}$

a. Pemberi atau penerima kuasa meninggal dunia, atau menjadi tidak waras. Hal ini bisa terjadi karena syarat sahnya perjanjian yakni hidup dan berakal sehat tidak terpenuhi.

b. Diberhentikanya pekerjaan yang dimaksud

c. Pencabutan kuasa oleh orang pemberikan kuasa

d. Tekait dengan hal ini para pengikut madzab Hanafi berpendapat: bahwa wajib ia (wakil) mengetahui pemutusan. Sebelum ia mengetahui hal itu, maka tindakanya tidak ubahnya seperti sebelum diputuskan, untuk segala hukumnya.

${ }^{12}$ Fatmah. Kontrak BIsnis Syariah. Hal 215

${ }^{13}$ Pasal 1813 KUHPerdata.

${ }^{14}$ Fatmah. Kontrak BIsnis Syariah. Hal 215-216 
e. Penerima kuasa memutuskan sendiri

f. Orang yang memberi kuasa keluar dari status kepemilikan.

3. Ketentuan Teknik dalam Perbankan

a. Wakalah dalam implikasi perbankan terjadi apabila nasabah memberikan kuasa kepada bank untuk mewakili dirinya melakukan pekerjaan jasa tertentu, seperti pembukuan $\mathrm{L} / \mathrm{C}$, inkaso dan transfer uang.

b. Bank dan nasabah yang dicantumkan dalam akad pemberian kuasa harus cakap hukum. Khususnya untuk pembukuan $\mathrm{L} / \mathrm{C}$, apabila dana nasabah ternyata tidak cukup, maka penyelesaian L/C dapat dilakukan dengan pembiayaan murabahah, salam, ijarah, mudharabah atau musyarakah.

c. Kelalaian dalam menjalankan kuasa menjadi tanggungjawab bank kecuali kegagalan karena force majeure menjadi tanggung jawab nasabah.

d. Apabila bank ditunjuk lebih dari satu, maka masingmasing bank tidak boleh bertindak sendiri-sendiri tanpa muusyawarah dengan bank yang lain, kecuali dengan seizin nasabah.

e. Tugas, wewenang dan tanggungjawab bank harus jelas sesuai kehendak nasabah bank. Setiap tugas yang dilakukan harus mengatasnamakan nasabah dan harus dilaksanakan oleh bank. Atas pelaksanaan tugasnya tersebut, bank mendapat pengganti biaya berdasarkan kesepakatan bersama.

Pemberian kuasa berakhir setelah tugas ilaksanakan dan disetujui bersama antara nasabah bank.

\section{Aplikasi Akad Wakalah Dalam Perbankan Syariah}

1. Transfer dan Inkas

Akad wakalah dalam perbankan syariah diterapkan adalam transfer uang. Dalam hal ini bank bertindak sebagai wakil dari nasabah untuk mentransfer sejumlah dana atau uang yang diamanahkan, atas jasanya tersebut pihak bank berhak untuk menerima imbalan berupa ujrah atau fee dari 
nasabah. Demikian pula dalam inkaso bank mewakili nasabah dalam hal penagihan untuk untung rekening nasabah dan bank berhak menerima imbalan.

Dengan adanya produk dengan akad tersebut nasabah mendapat kemudahan dalam bertransaksi dan resiko dari transaksi tersebut berupa resiko operasional terkait human error ataupun fraud kerusakan/gangguan/kegagalan pada hardware, software, atau jaringgan telekomunikasi. Selain itu juga perlu diperhatikan ketentuan kehati-hatian terkait upaya mengatasi tindak pidana pencucian uang menggunakan fasilitas transfer.

2. Letter of Credit Syariah

L/C import adalah surat pernyataan akan membayar kepada eksportir (beneficiary) yang diterbitkan oleh bank syariah (issuing bank) atas permintaan atau untuk kepentingan importir dengan pemenuhan persyaratan tertentu sesuai dengan prinsip syariah. Dalam L/C import syariah yang berdasarkan akad-akad wakalah bil ujrah, bank syariah bertindak sebagai wakil sekaligus sebagai penjamin importir dalam melakukan pembayaran dan nasabah sebagai muwakil. Bank harus bertindak melaksanakan semua yang telah diwakilkan kepadanya dan nasabah harus memerinci hal-hal apa saja yang harus diwakilkan bank sehingga menjadi jelas dan tidak ada gharar. Sebelum mewakilkan pengurusan dokumen-dokumen transaksi import dan pembayaran, nasabah harus memiliki dana pada bank sebesar harga pembayaran barang import atau bisa juga bank memberikan dana talangan untuk pembayaran yang diberlakukan sebagai dana qardh, pembiayaan murabahah dengan pihak importir, atau pembiayaan modal kerja (musyarakah) kepada importir. Bank akan mendapatkan imbalan dalam bentuk marjin (menggunakan akad jual beli) ataupun bagi hasil.

Resiko dalam transaksi L/C import syariah adalah resiko pembiayaan (credit risk) dalam hal nasabah (importir) tidak membayar tagihan penyelesaian L/C. selain itu juga terdapat resiko likuiditas dalam hal bank sulit mendapat jenis valuta 
yang disyaratkan pada waktunya dan resiko reputasi dalam hal bank tidak dapat memenuhi komitmen yang disyaratkan. Resiko lainya terkait keandalan menejemen teknologi informasi (resiko operasional) serta resiko akad yang menyertai pemberian fasilitas L/C, misalnya akad murabahah dalam pembelian barang import. ${ }^{15}$

\section{Profil Baitul Mal wat Tamwil (BMT) Amanah Bersama Bojonegoro}

Lembaga CV. Amanah bersama sudah resmi berdiri sejak Januari 2009 dimana lembaga ini udah dirintis sejak tahun 1999 yang pada awalnya bergerak pada bidang jasa supplier air minum. Dan terus berkembang dan merambah ke beberapa bidang bisnis jasa lainya. Pada awal berdirinya alamat kantor pusatnya berada di kompleks pertokoan Jln. Gajah Mada No. 6 Kedungadem Bojonegoro. ${ }^{16}$

Saat ini BMT Amanah Bersama beralamat di Jln. Gajah Mada No. 148 B Depan Alamat Jln. Gajah Mada No. 148 B Depan SDN 1 Kedungadem Kecamatan Kedungadem Bojonegoro Telp: 082234867237.

Lembaga ini didirikan oleh Bambang Utomo sekaligus direktur utama Lembaga Amanah Bersama.

Berbadan hukum resmi : REZA P. KALIA, SH. Bojonegoro; No. 9/1/2009

No. TDP

$: 131639300083$

No. SIUP

: 517/009/208.412/PM/2009

NPWP

: 21.074.252.4-601-000

Lembaga ini merupakan lembaga keuangan berupa koperasi yang berbasis syariah. Koperasi ini berbentuk Baitul Mal wat Tamwil (BMT) yang merupakan lembaga mikro yang dioperasikan dengan prinsip bagi hasil, menumbuhkembangkan bisnis usaha mikro dalam rangka

Rachmad Usman, Produk Dan Akad Perbankan Syariah Di Indonesia Implementasi Dan Apek Hukumnya (Bandung: PT Citra Aditya Bakti, 2009), 274-276.

${ }^{16}$ Ayu, "Staf," Wawancara, Bojonegoro, 12 Juni 2019. 
Nabillah Febri Annisa, Nabrina Nur Zeninda, Nadya Fatma Kholili, Rosa Novitasari Aisyah, Ulil Ala'i

mengangkat derajat dan martabat serta membela kepentingan kaum fakir miskin.

"BMT Amanah Bersama" adalah BMT simpan pinjam berlandaskan syariah, selain simpan pinjam BMT Amanah Bersama juga melayani arisan umrah, motor, kredit handphone dan lain-lain. BMT Amanah Bersama melayani nasabah mulai hari senin hingga sabtu dari pukul 07:30-15:30 WIB.

BMT Amanah Bersama mempunyai motto "Melayanimu Ibadahku". Adapun visinya adalah Menjadikan BMT yang mandiri, bermartabat, barokah, menentramkan bagi anggota dan masyarakat. Berdasarkan visi tersebut, maka BMT memiliki misi untuk:

1. Mengembangkan ekonomi berbasis syariah.

2. Menjadi mitra usaha bagi anggota dan masyarakat kecil menengah ke bawah.

3. Membantu memudahkan anggota dan masyarakat dalam memenuhi kebutuhan hidup.

4. Menjalankan fungsi sosial kod anggota masyarakat.

5. Menjadi wahana bagi anggota untuk berinvestasi secara aman dan nyaman sesuai syariah.

6. Mengutamakan kesejahteraan bersama.

7. Kreatif, inovatif dan profesional dalam tata kelola.

8. Membudayakan dalam bermuamalah secara syari'i, berakhlaqul karimah, jujur, amanah dan adil. ${ }^{17}$

Selain visi misi, BMT memiliki tujuan. Tujuan didirikannya BMT Amanah Bersama adalah meningkatkan kesejahteraan anggota khususnya dan masyarakat pada umumnya serta turut membangun tatanan perekonomian yang berkeadilan sesuai dengan prinsip-prinsip ekonomi Islam. ${ }^{18}$

Untuk menjadi lembaga yang seperti sekarang ini lembaga ini melalu banyak sekali pasang surut usaha antara

\footnotetext{
17 “Brosur KSPP Syariah BMT Amanah Bersama," 2019.

${ }^{18}$ Ibid.
} 
lain yang paling sering adalah krisis kepercayaan tapi dengan usaha, do'a serta tanggunng jawab dan konsistensi untuk selalu mengedepankan kepuasaan bagi konsumen sehingga menjadikan lembaga tersebut terus mengalami perkembangan hingga sampai saat ini.

Untuk saat ini lembaga Amanah Bersama melayani berbagai bidang usaha antara lain supplier air minum, instalator depot air minum, termasuk juga usaha pelayanan jasa berupa pembiayaan bersama arisan: mobil, rumah, motor, laptop, lembu, dan lain-lain. Khusus untuk BMT nya sendiri baru berdiri tahun lalu bulan November 2018.

Struktur Keanggotaan Lembaga BMT Amanah Bersama

1. Dewan Pembina : M. Suyuti, S.Ag, M.Pd.I

2. Direktur Utama : Bambang Utomo, MM

3. Direktur Marketing : Suyitno, SE, M.Si

4. Manager Keuangan : Isropin, A.Ma. Pd

5. Administrasi Umum : Dewi Indah Prasticasari

6. Kabag Realisasi : Moch. Khoyum

7. Customer Service : Danang Agus Wijayanto, Amd.Komp

8. Debt Collector : Irpan Yusuf

\section{Produk BMT Amanah Bersama Bojonegoro}

Produk yang ditawarkan di BMT Amanah Bersama Bojonegoro adalah produk simpanan dan produk pembiayaan. Produk simpanan simpanan terdiri dari Simpanan hari raya idhul fitri, Simpanan untuk aqiqah, Simpanan untuk qurban, Simpanan pendidikan, Simpanan haji, dan Simpanan umrah.

Produk pembiayaan yang ditawarkan BMT Amanah Bersama Bojonegoro adalah Mudharabah (bagi hasil), Murabahah (jual beli), Musyarakah (kerja sama modal usaha), 
Wakalah (perwakilan), Hawalah (take over), dan Ijarah (sewa menyewa). ${ }^{19}$

Produk Pembiayaan yang paling banyak digunakan adalah Murabahah dimana nasabah dan pihak BMT Amanah Bersama melakukan perjanjian jual beli berupa pembiayaan suatu barang. Namun tidak menutup kemungkinan produkproduk lainnya tidak digunakan. Pihak BMT Amanah Bersama tetap menyediakan produk-produk lain, hanya saja untuk menentukan produk yang akan digunakan disesuaikan dengan kebutuhan nasabah.

Pada akad murabahah ini didalamnya juga bisa terdapat akad lain, contoh akad wakalah (perwakilan) dimana dalam pembiayaan suatau barang pihak BMT Amanah Bersama bertindak sebagai wakil yang mewakili mencarikan barang yang dibutuhkan nasabah. Kemudian nasabah melakukan pembiayaan dengan BMT Amanah Bersama dengan akad murabahah, sehingga nasabah mengangsur harga barang langsung ke BMT Amanah Bersama dengan ujroh yang telah disepakati diawal. Jadi akad wakalah di BMT Amanah Bersama tidak berdiri sendiri akan tetapi membutuhkan akad lain sebagai akad utamanya yaitu murabahah. ${ }^{20}$

\section{Syarat Pengajuan Produk pada BMT Amanah Bersama}

Untuk mengajukan produk pada BMT Amanah Bersama, nasabah harus memenuhi syarat-syarat, di antaranya adalah syarat keanggotaan dan syarat pembiayaan.

Syarat Keanggotaan adalah:

1. Menyerahkan fotocopy data diri

2. Mengisi formulir keanggotaan

3. Menyetorkan simpanan pokok Rp. 100.000

4. Menyetorkan simpanan wajib Rp. 5.000/Bulan

Persyaratan pembiayaan adalah:

1. Telah menjadi anggota BMT Amanah Bersama

\footnotetext{
19 "Brosur KSPP Syariah BMT Amanah Bersama."

${ }^{20}$ Ayu, "Staf."
} 
2. Memiliki simpanan di BMT Amanah Bersama

3. Memiliki usaha

4. Fotocopy (KTP, SIM, KK)

5. Jaminan/agunan asli (Sertifikat, BPKB dll)

6. Fotocopy buku nikah

7. Bersedia di survey. ${ }^{21}$

Khusus untuk syarat dan ketentuan pengajuan kredit handphone yang dilakukan antara BMT Amanah Bersama bekerjasama dengan Salsa seluler:

1. KK asli

2. Fotocopy KTP

3. Simpanan pokok Rp. 100.000

4. Simpanan wajib Rp. 5.000 (setiap bulan)

5. Admin Rp. 15.000

6. DP (tergantung merk handphone yang dikehendaki).22

\section{Cara Membuat Kontrak}

Mengenai mekanisme pembuatan kontrak di BMT Amanah Bersama adalah melalui proses dan tahapan berikut:

1. Pengajuan pembiayaan dan pengisian formulir lengkap oleh pihak nasabah serta ketentuan akad.

Dalam formulir tersebut nasabah dapat menentukan jenis pembiayaan dan jenis pembayaran (Bulanan/Musiman 3 bulan) yang akan digunakan serta sistem angsuran pembayaran ( 6 bulan, 8 bulan, 10 bulan, 12 bulan).

2. Survey terhadap calon nasabah

Survey dilakukan dengan cara melihat data dari calon nasabah, kemudian pihak BMT Amanah Bersama yang bertugas akan mendatangi kediaman dari calon nasabah, atau menggali data mengenai nasabah dengan cara bertanya mengenai sifat, kebiasaan dari calon nasabah malalui keluarga atau tetangga sekitar daerah kediaman calon nasabah. Sehingga pihak dari BMT Amanah Bersama

21 "Brosur KSPP Syariah BMT Amanah Bersama."

22 BMT Amanah Bersama, "Dokumen” (Bojonegoro, 2019). 
dapat menilai apakah calon nasabah tersebut mempunyai karakter baik atau tidak.

3. Penentuan ACC atau tidak

Tergantung pada hasil survey, apabila calon nasabah tersebut dapat ternilai mempunyai karakter yang baik maka pihak BMT Amanah Bersama akan melanjutkan akadnya.

4. Penyertaan jaminan/agunan

Apabila pembiayaan di ACC maka nasabah harus menyerahkan jaminan/agunan dimana agunan tersebut ditentukan berdasarkan besarnya platform atau nominal yang yang dibutuhkan nasabah.

a. Untuk platform/nominal 1-2 juta maka agunan berupa KK atau buku nikah

b. Untuk platform/nominal 2 juta keatas maka agunan berupa Sertifikat atau BPKB

c. Agunan bisa juga ditentukan berdasarkan besarnya DP yang diberikan nasabah misalkan apabila nasabah melakukan pembiayaan dengan nominal Rp. 2.300.000 dan menyertakan DP Rp. 1.000.000 maka agunannya boleh menggunakan KK asli atau buku nikah asli saja.

5. Pemberian surat pernyataan kesanggupan pembayaran kepada pihak nasabah atas pembiayaan tersebut serta surat rekomendasi untuk pengambilan barang yang dilakukan oleh nasabah sendiri ke tempat barang yang di butuhkan nasabah tersebut. ${ }^{23}$

Akad yang sering digunakan dari BMT Amanah Bersama adalah akad murabahah, akan tetapi BMT tetap menyediakan akad-akad lain termasuk akad wakalah. Dalam akan murabahah tersebut didalamnya juga terdapat akad wakalah atau akad ijarah muntahiyah bi tamlik.

Skema akad wakalah di BMT Amanah Bersama Bojonegoro adalah sebagai berikut:

${ }^{23}$ Ayu, "Staf." 


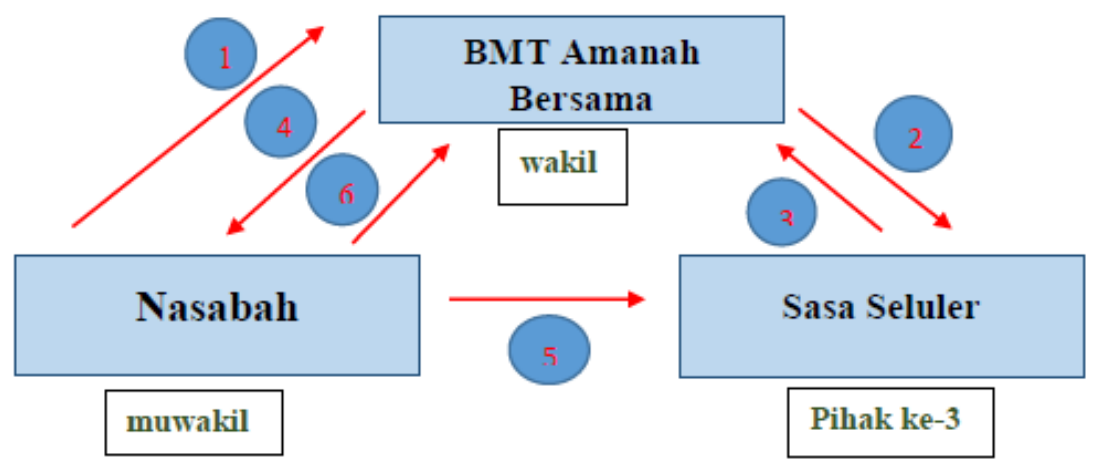

Keterangan:

1. Nasabah mengajukan pembiayaan ke BMT Amanah Bersama dengan akad wakalah untuk pembelian HP.

2. Setelah dilakukan survey dan di ACC maka pihak BMT sebagai wakil akan membelikan HP tersebut ke Sasa Seluler selaku mitra kerja

3. Sasa seluler menerima pemberitahuan mengenai pembelian HP

4. Pihak BMT memberikan berupa surat rekomendasi kepada pihak nasabah untuk pengambilan HP yang sudah dibeli oleh BMT Amanah Bersama ke Sasa Seluler langsung.

5. Nasabah mengambil HP yang sudah dibelikan BMT Amanah Bersama.

6. Nasabah akan membayar harga HP tersebut kepada pihak BMT dengan akad jual beli atau ijarah (Ijarah Muntahiyah Bil Tamlik).

Pelaksanaan akad wakalah dalam BMT Amanah Bersama tidak dapat berdiri sendiri harus dibarengi dengan akad yang lainya seperti akad Murabahah atau Ijarah (Ijarah Muntahiyah Bi Tamlik).

\section{Analisis Hukum Islam terhadap Praktik Akad Wakalah pada BMT Amanah Bersama Bojonegoro}

Usaha perusahaan pembiayaan dengan prinsip syariah dalam analisa ini yaitu BMT Amanah Bersama Bojonegoro. BMT Amanah Bersama ini menyediakan beberapa produk akad-akad dengan prinsip Islam, akan tetapi sesuai dengan 
tujuan kunjungan edukasi ini serta tema yang telah ditentukan sebelumnya maka penulis akan membahas bagaimana perspektif akad akad wakalah dalam Hukum Islam.

Dimana telah dijelaskan bagaimana operasional akad wakalah di BMT Amanah Bersama Bojonegoro. Pada dasarnya akad yang paling banyak digunakan adalah akad murabahah. Karena dalam pembiayaan akad murabahah tidak serumit yang terdapat pada perbankan syariah. Di BMT ini akad murabahah tidak terlepas dari akad wakalah, dimana akad wakalah digunakan sebagai sarana untuk mewakilkan secara syariah. BMT disini berperan sebagai pemberi kuasa kepada calon nasabah yang akan membeli barang sesuai dengan kesepakatan perjanjian. Dalam kasus-kasus yang ada pada BMT ini yang menggunakan akad murabahah, BMT menggunakan akad wakalah agar nasabah dapat membeli barang sebagai wakil dari BMT untuk membeli barang secara tunai.

Dalam menerapkan akad wakalah sendiri tidak terlepas dari rukun dan syarat-syarat serta dasar hukum yang mengatur tentang akad ini. Akad wakalah merupakan akad pelimpahan kekuasaan oleh seseorang sebagai pihak pertama kepada orang lain sebagai pihak kedua dalam hal-hal yang diwakilkan (dalam hal ini pihak kedua) hanya melaksanakan sebatas kuasa atau wewenang yang diberikan oleh pihak pertama, namun apabila kuasa tersebut telah dilaksanakan sesuai yang diisyaratkan, maka semua resiko dan tanggungjawab atas dilaksanakannya perintah tersebut sepenuhnya menjadi tanggung jawab pihak kedua atau pemberi kuasa.

Dasar hukum yang dipakai dalam fatwa tersebut sama yaitu QS. Al-Kahfi ayat 19. Adapun rukun dan syarat akad wakalah menurut jumhur ulama, rukun akad wakalah ada empat, yaitu:

1. Orang yang mewakilkan (muwakil)

2. Orang yang mewakili (wakil)

3. Sesuatu yang diwakilkan (al-muwakkalfih)

4. Sighat (ucapan yang menunjukkan ijab dan qabul) 
Syarat-syarat akad wakalah:

1. Syarat-syarat sighat, ada dua syarat sighat antara lain:

a. Akad wakalah berlangsung dengan lafal yang menunjukkan adanya keridhaan terhadap perwakilan itu baik secara terang-terangan maupun tidak.

b. Menurut imam Syafi'i, akad wakalah tidak dikaitkan dengan syarat.

2. Syarat orang yang mewakilkan (muwakkil)

Pemilik kewenangan untuk melakukan tindakan terhadap sesuatu yang dia wakilkan dan semua konsekuensi hukum tindakan itu berlaku padanya.

3. Syarat orang yang mewakili (wakil)

Orang yang mewakili harus berakal sehat, mengetahui transaksi pembiayaan dengan baik, mengetahui perbedaan ghaban al-yasir dengan ghaban al-Fahisy

4. Syarat objek yang diwakilkan

Objek akad harus jelas speknya, dan jelas keberadaannya.

Akad wakalah harus senantiasa memenuhi prinsip syariah Islam, termasuk fatwa-fatwa yang ditetapkan oleh Dewan Syariah Nasional Majelis Ulama Indonesia. Wakalah dalam Peraturan Otoritas Jasa Keuangan Nomor 31/P0JK.05/2014 tentang Penyelenggaraan Usaha Pembiayaan Syariah didefinisikan sebagai pemberian kuasa dari pemberi kuasa (muwakkil) kepada penerima kuasa (wakil) dalam hal yang boleh diwakilkan, dimana penerima kuasa (wakil) tidak menanggung risiko terhadap apa yang diwakilkan, kecuali karena kecerobohan atau wanprestasi. sedangkan wakalah bil ujrah didefinisikan sebagai wakalah dengan pengenaan imbal jasa (ujrah). ${ }^{24}$ Wakalah adalah salah satu akad yang digunakan dalam kegiatan pembiayaan jasa perusahaan pembiayaan syariah.

Pasal 1 angka 9 Peraturan Otoritas Jasa Keuangan Nomor 31/P0JK.05/2014 tentang Penyelenggaraan Usaha

24 Otoritas Jasa Keuangan, "Peraturan Otoritas Jasa Keuangan Nomor 31/POJK.05/ 2014 Tentang Penyelenggaraan Usaha Pembiayaan Syariah," 2014. 
Pembiayaan Syariah menyebutkan bahwa pembiayaan jasa adalah pemberian/penyediaan jasa baik dalam bentuk pemberian manfaat atas suatu barang, pemberian pinjaman (dana talangan) dan/atau pemberian pelayanan dengan dan atau tanpa pembayaran imbal jasa (ujrah) sesuai dengan perjanjian pembiayaan syariah yang disepakati oleh para pihak.

Fatwa DSN MUI Nomor 10/DSN-MUI/IV/2000 tentang Wakalah menyebutkan sebagai berikut:

1. Pernyataan ijab dan qabul harus dinyatakan oleh para pihak untuk menunjukkan kehendak mereka dalam mengadakan kontrak (akad).

2. Wakalah dengan imbalan bersifat mengikat dan tidak boleh dibatalkan secara sepihak.

3. Syarat-syarat muwakkil (yang mewakilkan)

a. Pemilik sah yang dapat bertindak terhadap sesuatu yang diwakilkan.

b. Orang mukallaf atau anak mumayyiz dalam batas-batas tertentu, yakni dalam hal-hal yang bermanfaat baginya seperti mewakilkan untuk menerima hibah, menerima sedekah dan sebagainya.

4. Syarat-syarat wakil (yang mewakili)

a. Cakap hukum,

b. Dapat mengerjakan tugas yang diwakilkan kepadanya,

c. Wakil adalah orang yang diberi amanat.

5. Hal-hal yang diwakilkan

a. Diketahui dengan jelas oleh orang yang mewakili,

b. Tidak bertentangan dengan syari'ah Islam,

c. Dapat diwakilkan menurut syari'ah Islam..$^{25}$

Berdasarkan dasar hukum di atas, perusahaan pembiayaan syariah BMT ini dapat menerima pendapatan yang diperoleh melalui akad wakalah. Karena lembaga keuangan ini menggunakan profit jadi dalam akad wakalah ini

${ }^{25}$ Dewan Syariah Nasional Majelis Ulama Indonesia, "Fatwa DSN MUI Nomor 10/DSN-MUI/IV/2000 Tentang Wakalah." 
terdapat ujrah (fee) yang digunakan sebagai timbal balik antara lembaga BMT tersebut dengan nasabah, dikarenakan pihak BMT disini telah melakukan sesuatu untuk kepentingan nasabah maka ia berhak mendapatkan ujrah atau imbalan. Maka dari kedua belah pihak akan merasa saling diuntungkan. Dan dalam BMT ini juga akad wakalah terdapat produk yang dihasilkan seperti tabungan haji dan umroh namun dalam lembaga BMT ini masih dalam tahapan proses.

Sesuai dengan pengertian wakalah dalam Pasal 1 angka 22 Peraturan Otoritas Jasa Keuangan Nomor 31/P0JK.05/2014, maka perusahaan pembiayaan syariah dapat berkedudukan sebagai pemberi kuasa (muwakkil) maupun sebagai penerima kuasa (wakil). Dan dalam lembaga ini BMT bertindak sebagai penerima kuasa (wakil) dan nasabah sebagai pemberi kuasa (muwakkil) yang berarti pihak BMT ini yang mencarikan barang untuk nasabah. Dalam lembaga ini implementasi akad wakalah dengan lembaga BMT sebagai penerima kuasa adalah pada pembiayaan dengan akad murabahah. Karena dalam lembaga ini akad wakalah tidak bisa terlepas dari akad murabahah kedua akad ini saling melengkapi.

Murabahah sendiri adalah jual beli suatu barang dengan menegaskan harga belinya (harga perolehan) kepada pembeli dan pembeli membayar-nya dengan harga lebih (margin) sebagai laba sesuai dengan kesepakatan kedua belah pihak. Seperti akad pembiayan murabahah, ketika perusahaan pembiayaan syariah harus mewakilkan pembelian barang kepada konsumen, maka hal itu dilakukan untuk lebih memberikan manfaat bagi perusahaan pembiayaan syariah dan konsumen. Konsumen dapat langsung mengecek barang dari penyedia atau supplier dan mendapatkan informasi tentang standar manual prosedur barang serta kartu garansi. Di sisi lain, perusahaan pembiayaan syariah diuntungkan dapat memberikan service yang lebih meyakinkan untuk konsumen serta lebih efisien dalam teknis pembiayaan. Jadi dapat disimpulkan bahwasanya akad wakalah yang telah 
Nabillah Febri Annisa, Nabrina Nur Zeninda, Nadya Fatma Kholili, Rosa Novitasari Aisyah, Ulil Ala'i

dijalankan oleh BMT Amanah Bersama sesuai dan tidak bertentangan dengan syariat Islam.

\section{Penutup}

BMT Amanah Bersama Bojonegoro menyediakan beberapa produk simpanan dan pembiyaan dengan syarat dan prosedur yang telah ditentukan. Dalam BMT Amanah Bersama pembiayaan yang paling serig digunakan adalah akad murabahah akan tetapi tetap tidak mengesampingkan akadakad lain seperti akad wakalah.

Wakalah adalah pelimpahan kekuasaan oleh seseorang sebagai pihak pertama kepada orang lain sebagai pihak kedua dalam hal-hal yang diwakilkan. Pihak pertama adalah pemberi kuasa dan pihak kedua adalah penerima kuasa yang menjalankan kuasa sesuai dengan yang diamanatkan oleh pihak pertama.

Akad wakalah di BMT Amanah Bersama tidak berdiri sendiri akan tetapi dari akad wakalah pihak BMT dapat menerima pendapatan yang diperoleh melalui ujrah (fee) yang mana ini digunakan sebagai timbal balik antara lembaga BMT tersebut dengan nasabah agar kedua-keduanya saling menguntungkan.

Akad wakalah di BMT Amanah Bersama telah memenuhi rukun dan syarat wakalah. Rukun wakalah adalah Muwakil atau pelaku akad (pemberi kuasa), Wakil (penerima kuasa), Taukil, yaitu objek akad, Sighat yaitu ijab dan qabul. Dalam hal ini nasaba sebagai muwakil, BMT Amanah Bersama sebagai Wakil, barang sebagai objek taukil misal membeli handphone dan shighatnya berupa ijab qabul yang tertuang dalam kontrak. Hal tersebut didasarkan pada dasar hukum dari akad wakalah yang berasal dari Al-Quran surat al-Kahfi: 19 dan surat Yusuf: 55, Hadis, Ijma' Ulama', dan fatwa DSN Nomor 10/DSNMUI/IV/2000.

\section{Daftar Pustaka}

Antonio, Muhammad Syafii. Bank Syariah: Dari Teori Ke Praktik. 
Jakarta: Gemma Insani, 2001.

Ascarya. Akad Dan Produk Bank Syariah. Jakarta: Rajawali Press, 2013.

Ayu. "Staf." Wawancara, Bojonegoro, 12 Juni, 2019.

BMT Amanah Bersama. "Dokumen." Bojonegoro, 2019.

"Brosur KSPP Syariah BMT Amanah Bersama," 2019.

Dewan Syariah Nasional Majelis Ulama Indonesia. "Fatwa DSN

MUI Nomor 10/DSN-MUI/IV/2000 Tentang Wakalah." Jakarta, 2000.

Faqih, Aunur Rohim. Bank Syariah, Kontrak Bisnis Syariah, \& Penyelesaian Sengketa Di Pengadilan. Yogyakarta: FH UII Press, 2017.

Fatmah. Kontrak Bisnis Syariah. Surabaya: UIN Sunan Ampel Press, 2014.

Masyithoh, Novita Dewi. "Analisis Normatif Undang-Undang No. 1 Tahun 2013 Tentang Lembaga Keuangan Mikro (Lkm) Atas Status Badan Hukum Dan Pengawasan Baitul Maal Wat Tamwil (Bmt)." Economica: Jurnal Ekonomi Islam 5, no. 2 (2014): 17-36. https://doi.org/10.21580/economica.2014.5.2.768.

Muljadi. "Prospek Baitul Maal Wat Tamwil (BMT) Dalam Memajukan Pengusaha Mikro." Dynamic Management Journal 1, no. 2 (2017).

Otoritas Jasa Keuangan. "Peraturan Otoritas Jasa Keuangan Nomor 31/POJK.05/ 2014 Tentang Penyelenggaraan Usaha Pembiayaan Syariah," 2014.

Shiddieqi, Teungku Muhammad Hasby Ash. Hukum-Hukum Fiqh Islam. Semarang: PT Pustaka Rizki Putra, 2001.

Usman, Rachmad. Produk Dan Akad Perbankan Syariah Di Indonesia Implementasi Dan Apek Hukumnya. Bandung: PT Citra Aditya Bakti, 2009. 